\title{
Are the urban poor really worse off? Socioeconomic differentials in adult cause specific mortality at the periphery of Ouagadougou, Burkina Faso
}

\author{
CLÉMENTINE ROSSIER ${ }^{1,2}$ \\ ABDRAMANE BASSIAHI SOURA ${ }^{3}$ \\ GÉRALDINE DUTHÉ ${ }^{2}$ \\ BRUNO LANKOANDE ${ }^{3,4}$ \\ ROCH MILLOGO 3
}

\begin{abstract}
Résumé
Dans les pays les moins développés, tandis que les citadins les plus pauvres sont plus susceptibles de mourir de maladies transmissibles et de blessures, les plus riches pourraient souffrir d'un plus grand fardeau de maladies non transmissibles. II n'est donc pas évident de savoir si dans les villes africaines les adultes les plus pauvres sont en moins bonne santé que leurs homologues plus aisés. Dans cet article, nous décrivons les inégalités sociales qui caractérisent la mortalité des adultes (personnes de 15 à 59 ans) à la périphérie de Ouagadougou, capitale du Burkina Faso. En utilisant les données du Système de Surveillance Démographique et Sanitaire de Ouagadougou, de 2009 à 2011, nous vérifions si des facteurs tels que le niveau d'éducation, la pauvreté et la résidence en quartier informel sont liés au risque de décès prématuré chez les adultes. Nous menons cette analyse de la mortalité toutes causes confondues, et aussi en considérant trois grandes catégories de causes

1. Institut d'Études Démographiques et du Parcours de Vie (I-DEMO), Université de Genève, Suisse.

2. Institut National d'Études Démographiques, Paris, France.

3. Institut Supérieur des Sciences de la Population, Université de Ouagadougou, Burkina Faso.

4. Centre de recherche en démographie et société, Université catholique de Louvain, Belgique.
\end{abstract}


de décès : les maladies transmissibles, les maladies non transmissibles et les causes externes. En limitant l'analyse aux adultes nés à Ouagadougou, nous avons constaté que le citadin pauvre fait face à une pénalité sanitaire considérable comparativement au moins pauvre, ce qui est conforme aux attentes basées sur la littérature existante. Les non-migrants riches font face à des risques plus faibles de décès prématuré dû aussi bien aux maladies transmissibles qu'aux maladies non transmissibles. Les adultes migrants quant à eux présentent des tendances très différentes qui faussent l'image globale des inégalités de santé dans la ville. Les migrants riches et les migrants vivant dans les quartiers formels courent un plus grand risque de décès de maladies non transmissibles. Ces résultats particuliers sont probablement dus à des effets de sélection liés à la migration, et peut-être aussi à des niveaux plus élevés d'exposition à des maladies non transmissibles par les migrants. Ils appellent à une plus grande attention portée sur les effets de la migration lors d'études sur les différences rurales-urbaines ou les inégalités sociales de santé en Afrique sub-saharienne.

\section{Mots-clés}

Mortalité, migrants, villes, adultes, Afrique au sud du Sahara.

\section{Summary}

In the cities of less developed countries, while poorer residents are likely to be at greater risk of dying from communicable diseases and injuries, wealthier residents may suffer from a greater burden of non-communicable diseases. It remains thus unclear whether poorer African adult city dwellers are in worse health than their better-off counterparts. In this paper, we describe the social inequalities that characterize adult mortality (individuals aged 15 to 59) at the periphery of Ouagadougou, the capital city of Burkina Faso. Using data from the Ouagadougou Health and Demographic Surveillance System from 2009 to 2011, we test whether factors such as levels of education, poverty and informal settlement are related to risks of premature deaths among adults. We conduct this analysis for all-cause mortality, and also considered three main categories of causes of death: communicable diseases, non-communicable diseases and external causes. Restricting the analysis to adults born in Ouagadougou, we found that the urban poor face a considerable health penalty compared to the less poor, which is consistent with expectation based on existing literature. Wealthier non-migrants face relatively lower risks of premature death, from both communicable and non-communicable diseases. Adult migrants exhibit very different patterns of mortality, which distort the overall picture of health inequalities in the city. Wealthier adult migrants and migrants living in formal settlements face a greater risk of dying from non-communicable diseases. These particular patterns are probably due to selective in and/or out-migration, and maybe to greater levels of exposure to non-communicable diseases by migrants. These results call for more attention to the effects of migration when studying rural-urban and social differentials of health in Sub-Saharan Africa.

\section{Key words}

Mortality, migrants, cities, adults, sub-Saharan Africa. 
Clémentine Rossier, Abdramane Bassiahi Soura, Géraldine Duthé,

Bruno Lankoande, Roch Millogo

\section{Introduction}

As in most developing countries, urban dwellers in Sub-Saharan Africa are, on average, healthier than their rural counterparts, which is consistent with their relatively wealthy status. Urban dwellers are indeed richer, more educated and enjoy a higher concentration of health services and public amenities (such as safe drinking water) than rural residents. However, researchers over the last two decades have increasingly questioned this «urban health advantage», pointing to the great health inequalities within cities that are masked in simple rural-urban comparisons. A number of studies have demonstrated that poor urban children, especially those living in slums, may very well be in worse health than children living in rural areas (Timaeus, Lush, 1995; Gould, 1998; Montgomery et al., 2004; Fotso, 2007; Bocquier et al., 2011b; Günther, Harttgen, 2012). Results of the 2008-09 Kenya Demographic and Health Survey provide a striking illustration of the «urban penalty» faced by many urban poor: the child mortality rate is 151 per 1000 live births in Nairobi's slums, as opposed to 62 per 1000 for the entire capital and 113 in rural Kenya (KNBS, 2010).

Some explanations have been proposed for the magnitude of health inequalities that characterize cities of the developing world. First, even if health services are relatively abundant in the urban context, health insurance schemes are rare, and the procurement of medical care remains costly. Although economic factors are not always decisive at the macro level (some poor countries, like Cuba and China, have efficient health systems for most of their citizens, Cutler et al., 2006), in Sub-Saharan African countries where health systems remain weak, individual incomes continue to be a key factor in accessing health services. Personal wealth, thus, remains a key determinant of health inequalities, including within cities (Montgomery, Hewett, 2005; James et al., 2006).

Secondly, many poor residents live in informal urban settlements which provide unsanitary living conditions (Baker, Schuler, 2004; WHO, UN HABITAT, 2010). These areas are characterized by a lack of public services (including clean water and sanitation) and high population densities, which are conducive to infectious diseases. Exposure to environmental hazards stemming from pollutants may also be high as these areas are often located in unhealthy parts of town near factories or garbage dumps. The unplanned nature of these settlements exposes residents to risk of accidents. Moreover, adults living in these neighborhoods have been found to be at a high risk of crime, violence and unsafe sexual encounters leading to HIV/AIDS (Kyobutungi et al., 2008). 
Though urban children born to disadvantaged parents (especially those living in unsanitary informal neighborhoods) are clearly in worse health than wealthier urban children, the relationship between poverty and poor health may be weaker among adult city dwellers. Disadvantaged urban adults certainly have lower rates of health care utilization. However, poor adults living in informal settlements do not necessarily suffer from a disproportionate burden of infectious diseases, because adults are less vulnerable than children to these ailments. Furthermore, some informal settlements do not suffer elevated rates of crime and violence, as in the case of Ouagadougou (Pison et al., 2012). On the other hand, wealthier adults (who live most often in formal areas) may be the most rapid adopters of unhealthy lifestyles (fat and sugary diets, alcohol use, tobacco use), which may expose them to an even greater burden of noncommunicable diseases than poor urban residents. The literature on this issue in Sub-Saharan Africa remains scant, with the existing data suggesting that cardiovascular diseases are more prevalent among the rich (Dalal et al., 2011). In Ouagadougou, wealth has been associated with smoking and being overweight (Ouedraogo et al., 2008; Zeba et al., 2012; Koueta et al., 2009). Finally, health care provision may be inadequate for non-communicable diseases, especially in the least developed countries of the continent, and wealthier urban dwellers may not have access to better care when it comes to chronic conditions. Some evidence indicates that the provision of health services for non-communicable diseases and injuries is largely insufficient in Sub Saharan African cities, and remains prohibitively expensive even for the wealthy (Macia et al., 2011; Lagarde, 2007). It remains unclear then whether poorer African adult city dwellers face worse health than their wealthier counterparts, given the possibly contradictory effects of several factors at this particular stage of the health transition.

In this paper, to explore the relationship between health and poverty among adult city dwellers, we describe the socioeconomic inequalities characterizing adult mortality (individuals aged 15 to 59) at the periphery of Ouagadougou, the capital city of Burkina Faso. Using data from the Ouagadougou Health and Demographic Surveillance System from 2009 to 2011, we test whether factors such as level of education, poverty and informal settlements are related to risks of premature deaths among adults. For this analysis, we consider all-cause as well as three main categories of causes of death: communicable diseases, non-communicable diseases and external causes.

Health and Demographic Surveillance System (HDSS) data offer several advantages. First, HDSSs record the dates of demographic events 
Clémentine Rossier, Abdramane Bassiahi Soura, Géraldine Duthé,

Bruno Lankoande, Roch Millogo

(births, deaths, in and out migrations), longitudinally at least once a year, which provides more reliable estimates of the person-years lived compared to retrospective data collected in surveys. This, in turn, contributes to more reliable estimates of mortality. Moreover, by conducting verbal autopsies (VAs) for deaths recorded, HDSSs appear as one of the few reliable sources of data on causes of death in developing countries where many deaths occur outside the hospital and are never reported.

\section{Data and methods}

\section{Context and population}

The Ouagadougou Health and Demographic Surveillance System (Ouaga HDSS) is a platform for health research and interventions established in 2008 in five neighborhoods of Ouagadougou (Rossier et al., 2012). Two of these neighborhoods (Kilwin, Tanghin) are formal neighborhoods with full access to public services, while the other three (Nonghin, Polesgo, Nioko) are unplanned and informal peri-urban settlements (i.e. slums) without access to such services. People living in informal areas are more often poor, uneducated and born in rural areas than people living in formal areas (Rossier et al., 2011). Households in the informal areas are usually small, composed of single men or young nuclear families, who flock to informal plots in search of affordable housing. These young families build houses there in the hopes that, when the city formally allocates the land, their claim will be staked.

After an initial census conducted between October 2008 and March 2009 in the five neighborhoods, Ouaga HDSS fieldworkers conducted periodic household update rounds (with an average periodicity of 10 months), registering vital events (births and deaths), marriages and migrations. As of November 2012, the population under surveillance by the Ouaga HDSS totaled 86,071 residents (defined as individuals present in the zone for at least six months).

In the event of a death, a verbal autopsy questionnaire is filled with the next of kin (with the consent of the family) to determine the circumstances that led to the death, including history of the illness and the specific symptoms that preceded death. This verbal autopsy protocol is approved by the World Health Organization and is used by members of the INDEPTH Network (the International Network for the Demographic 
Evaluation of Populations and Their Health). Results of the verbal autopsy are entered into InterVA4 software (also approved by the WHO) to determine the probable cause of death (http://www.who.int/ healthinfo/statistics/verbalautopsystandards/en/).

Data for this analysis cover the time period 2009-2011 and include 331 deaths recorded among 63'762 individuals aged 15-59. This population under consideration contributed a total of 130'116.4 person-years. Of the 331 recorded deaths, 265 VAs were completed. Among the reasons for the VA being not done (66 in total), family move is the leading cause, with $79 \%$ of cases. Refusals and the absence of an ideal respondent account for $10.5 \%$ each. In $75 \%$ of VAs cases not done because of family move, the deceased was the head of the household; in $18 \%$ of cases, the deceased was the wife of the head.

Among the 265 VA which were done, the InterVA4 software was able to assign a cause of death to $94.3 \%$ of them. The results show that tumors (mostly of the throat, digestive tract, respiratory system and breast) are the leading causes of death among these Ouagalese adults, accounting for $22.3 \%$ of the deaths. Cardiovascular diseases are the next leading cause of death, responsible for $14.7 \%$ of the deaths, followed by injuries (8.7\%), HIV/AIDS (8.3\%), respiratory infections (6.8\%), TB (6.4\%), malaria (3.8\%) and maternal mortality (3.4\%). Other causes of death exist in small numbers (Table 1).

TABLE 1 Distribution (\%) of deaths by cause of death

\begin{tabular}{|l|c|c|}
\hline Grouped causes of death by InterVA-4 & Frequences & Percentage \\
\hline Neoplasms & 59 & 22.3 \\
\hline Cardiovascular diseases & 39 & 14.7 \\
\hline Injuries & 23 & 8.7 \\
\hline HIV/AIDS & 22 & 8.3 \\
\hline Respiratory infections & 18 & 6.8 \\
\hline Tuberculosis & 17 & 6.4 \\
\hline Malaria & 10 & 3.8 \\
\hline Direct obstetric causes & 9 & 3.4 \\
\hline Asthma & 7 & 2.6 \\
\hline Meningitis & 6 & 2.3 \\
\hline Diabetes Mellitus & 5 & 1.9 \\
\hline Diarrhoeal diseases & 2 & 0.7 \\
\hline Malnutrition & 2 & 0.7 \\
\hline Liver diseases & 1 & 0.4 \\
\hline Other & 30 & 11.3 \\
\hline Indeterminate & 15 & 5.7 \\
\hline Total & 265 & 100 \\
\hline
\end{tabular}


For our analysis, the dependent variable is the risk of death between the ages of 15 and 59. This risk is analyzed both for all causes (including the deaths from an unknown cause) as well as for three groups of causes: communicable diseases (including HIV/AIDS, diarrheal diseases, direct obstetric, infectious diseases, malaria, malnutrition, meningitis, neonatal causes, respiratory tract Infection, TB), non-communicable diseases (including anemia, asthma, cardio-vascular, chronic obstructive pulmonary disease, diabetes mellitus, liver disease, neoplasm, acute abdomen, epilepsy, other unspecified non communicable diseases) and external causes of death (injuries). This grouping ensures that there are enough cases in each group for a cause-specific mortality analysis.

Three variables allow for the definition of the urban poor: the material standard of living, the level of formal education, and the type of neighborhood they live in (either formal or informal). To maintain large enough sample sizes, education level and standard of living were transformed into dichotomous variables (educated/uneducated; poor/not poor). Standard of living was measured by a proxy which, for each household, takes into account the number and types of material goods in a home (i.e. a television or a refrigerator), as well as the most «valuable» means of transportation present in the home (none, bicycle, motor scooter, car). A poor household has no television, refrigerator, motor scooter or car. We use sex and age as control variables. With regards to age, although it is introduced as a continuous variable in our models, we grouped it into two categories (15-34 years and 35-59 years) in the bivariate analysis, which allows us to have enough cases in each group to compute mortality rates.

Table 2 presents the summary distribution of the person-years, with a distinction between migrants and native born. A native (non-migrant) is defined as someone who was born in Ouagadougou, while a migrant is defined as anyone born elsewhere, who moved to the capital city. We apply this same distinction to all the subsequent analyses on risk of death to test the possible effect of selective migration (Bocquier et al., 2011a). Information on place of birth was missing for $10.6 \%$ of the population considered (6'758 people). These missing values were imputed using multiple imputation (van Buuren et al., 1999; Raghunathan et al., 2001; Azur et al., 2011). This method usually produces more efficient estimates than the listwise deletion (Graham, 2009). Furthermore, unlike the mortality due to communicable and non-communicable diseases, the small number of deaths does not allow us to perform multivariate analysis of mortality due to external causes separately by migration status. 
As expected, the population is made up predominantly of young adults (less than 35 years of age), non-poor and educated (Table 2). It is relatively balanced between the sexes. Compared to migrants, fewer cityborn have no formal education or live in informal settlements.

TABLE 2 Characteristics of the person-years

\begin{tabular}{|c|c|c|c|}
\hline Variables & All residents & Non-migrants & Migrants \\
\hline \multicolumn{4}{|l|}{ Standard of living } \\
\hline Poor & $46^{\prime} 942.6(36.1 \%)$ & $11^{\prime} 907.7$ (28.9\%) & $35^{\prime} 034.8(39.4 \%)$ \\
\hline Not poor & $83^{\prime} 173.8(63.9 \%)$ & $29^{\prime} 273.3(71.1 \%)$ & $53^{\prime} 900.6(60.6 \%)$ \\
\hline \multicolumn{4}{|l|}{ Education } \\
\hline Not educated & $52^{\prime} 619.2(40.4 \%)$ & $9^{\prime} 334.6(22.7 \%)$ & $43^{\prime} 284.7(48.7 \%)$ \\
\hline Educated & $77^{\prime} 497.2(59.6 \%)$ & $31^{\prime} 846.4(77.3 \%)$ & $45^{\prime} 650.7(51.3 \%)$ \\
\hline \multicolumn{4}{|c|}{ Type of neighborhood } \\
\hline Informal & $57^{\prime} 983.2(44.6 \%)$ & $12^{\prime} 137.6(29.5 \%)$ & $45^{\prime} 845.5(51.5 \%)$ \\
\hline Formal & $72^{\prime} 133.2(55.4 \%)$ & $29^{\prime} 043.4(70.5 \%)$ & $43^{\prime} 089.9(48.5 \%)$ \\
\hline \multicolumn{4}{|l|}{ Sex } \\
\hline Male & $66^{\prime} 397.3(51.0 \%)$ & $20^{\prime} 839.0(50.6 \%)$ & $45^{\prime} 558.3(51.2 \%)$ \\
\hline Female & $63^{\prime} 719.1(49.0 \%)$ & $20^{\prime} 342.0(49.4 \%)$ & $43^{\prime} 377.1(48.8 \%)$ \\
\hline \multicolumn{4}{|l|}{ Age group } \\
\hline $15-34$ & $91^{\prime} 520.3(70.3 \%)$ & $33^{\prime} 048.3$ (80.3\%) & $58^{\prime} 472.0(65.7 \%)$ \\
\hline $35-59$ & $38^{\prime} 596.1(29.7 \%)$ & 8'132.7 (19.7\%) & $30^{\prime} 463.4(34.3 \%)$ \\
\hline Total & $130^{\prime} 116.4$ & $41^{\prime} 181.0$ & $88^{\prime} 935.4$ \\
\hline
\end{tabular}

\section{Demographic and statistical methods}

Classic mortality rates are obtained by comparing the number of deaths to the person-years of exposure to risk. Because of left and right censoring 5 , people do not have the same exposure time. Table 3 explains how exposure was considered as a function of the type of entry and the type of exit. In this table, the start date is the date of enumeration or the date of immigration.

We used Cox regression to test the effect of the independent variables on the risk of overall death. We implemented a competing-risks model (Fine, Gray, 1999) to test the effects on cause-specific mortality. The use of such a model is justified by the fact that individuals are simultaneously exposed to multiple risks of death. These risks (deaths of various causes) are competing, and the expression of one prevents the others from

5. There are different types of entry in the study (by the age group, by immigration or at the initial enumeration) and different types of exit (from the age group, by outmigration or the end of observation). 
taking place. In the competing-risks model, the event of interest is considered in competition with the other events, which are not distinguished from each other. In our case, death occurs as a result either of communicable diseases, of non-communicable diseases, of external causes, or of unknown cause (unspecified or VA not done). In other words, when we analyse a risk of interest (mortality from communicable diseases, for example), all other causes (including the unknown ones) are considered as competing causes.

TABLE 3 Exposure calculation as a function of the type of entry (in line) and the type of exit (in column) between January 1st, 2009 and December 31st, 2011

\begin{tabular}{|c|c|c|c|}
\hline & $\begin{array}{l}\text { Exit by out-migration } \\
\text { before December 31st, } \\
2011\end{array}$ & $\begin{array}{l}\text { Individual turning } \\
60 \text { during the follow } \\
\text { up }\end{array}$ & $\begin{array}{l}\text { Exit at the end of } \\
\text { observation (Decem- } \\
\text { ber 31st, 2011) }\end{array}$ \\
\hline $\begin{array}{l}\text { Individual in the } 15- \\
59 \text { age group before } \\
\text { the start date }\end{array}$ & $\begin{array}{l}\text { Difference between } \\
\text { the start date and the } \\
\text { date of out-migration }\end{array}$ & $\begin{array}{l}\text { Difference between } \\
\text { the start date and } \\
\text { 60th birthday }\end{array}$ & $\begin{array}{l}\text { Difference between } \\
\text { the start date and } \\
\text { December 31st, } 2011\end{array}$ \\
\hline $\begin{array}{l}\text { Individual turning } \\
15 \text { after the start } \\
\text { date }\end{array}$ & $\begin{array}{l}\text { Difference between } \\
\text { 15th birthday and the } \\
\text { date of out-migration }\end{array}$ & $\begin{array}{c}\text { / } \\
\text { (not possible in } 3 \\
\text { years of follow up) }\end{array}$ & $\begin{array}{l}\text { Difference between } \\
\text { 15th birthday and } \\
\text { December 31st, } 2011\end{array}$ \\
\hline
\end{tabular}

The Cox model and the competing-risks model test if the instantaneous risk (hazard or sub-hazard respectively) of experiencing the relevant event differs between groups ${ }^{6}$. These models rest on the "proportional hazards» assumption - that is, the relationship of hazards between individuals in two different groups is constant over time (in this case the length of stay in the HDSS).This assumption softens or even becomes useless if several covariates vary over time (Allison, 1995). In our case, aside from sex, all the covariates used are time-varying.

In each of our models, the explanatory variables are introduced in one step. Because the data analyzed are not sample data, we use bootstrap method with 100 replications to get robust confidence intervals. Also, it should be noted that considering a potential correlation between the three indicators of social inequality (standard of living, level of education, type of neighborhood) ${ }^{7}$, we tested their pair-wise interactions in

6. Hazard and sub-hazard ratios are interpreted exactly the same. Thus, we will call both «hazard ratios» when interpreting the results.

7. The sample indicates, for example, that $57 \%$ of adults in informal settlements are poor and $52 \%$ uneducated; $72 \%$ of uneducated adults are non-poor. 
the models (all-cause and cause-specific mortality analysis). None of these interaction effects were significant and we then decided to remove them from the models to simplify the interpretation of the results.

\section{Results}

\section{Descriptive results}

Table 4 presents mortality rates for all-cause and by the broad category of causes. It also shows the rates calculated with deaths for which no verbal autopsy has been performed, or for which the cause of death is left unspecified by the InterVA-4 software, although we will not comment on these results.

The mortality rate for adults aged 15-59 in the Ouaga HDSS between 2009 and 2011 is estimated at 2.5 deaths per 1'000 persons per year. According to the hypothesis that the mortality of children and the elderly weighs more heavily in all-age mortality, we can consider our results consistent with those of the 2006 census, which estimated the crude mortality rate for all ages at 5.6 per 1'000 in the Center region where Ouagadougou is located (Baya et al., 2009). We observe a relatively lower mortality rate among women regardless of cause (difference not significant however), and higher mortality rate among adults aged 35-59 compared to those aged 15-34.

All-cause mortality rate does not vary by standard of living, but is higher for the uneducated (Table 4). Mortality from communicable diseases is higher among the uneducated but does not change by type of neighborhood or standard of living. Non-communicable diseases mortality is higher for people in formal neighborhoods. However, this group of cause of death is not significantly related to education or wealth, although the poorer and more educated people are apparently less likely to die from non-communicable diseases. The mortality rate from external causes does not show any significant difference except that more males die from these causes. 
Clémentine Rossier, Abdramane Bassiahi Soura, Géraldine Duthé,

Bruno Lankoande, Roch Millogo

TABLE 4 Mortality rates (p. 1'000) by group of causes

\begin{tabular}{|c|c|c|c|c|c|}
\hline & $\begin{array}{c}\text { All } \\
\text { causes }\end{array}$ & $\begin{array}{c}\text { Communicable } \\
\text { diseases }\end{array}$ & $\begin{array}{c}\text { Non- } \\
\text { communicable } \\
\text { diseases }\end{array}$ & $\begin{array}{c}\text { External } \\
\text { causes of } \\
\text { death }\end{array}$ & $\begin{array}{l}\text { VA not done or } \\
\text { unspecified } \\
\text { cause of death }\end{array}$ \\
\hline \multicolumn{6}{|l|}{ Standard of living } \\
\hline Poor & $\begin{array}{c}2.6 \\
(2.1-3.1)\end{array}$ & $\begin{array}{c}0.8 \\
(0.6-1.1)\end{array}$ & $\begin{array}{c}0.8 \\
(0.6-1.1)\end{array}$ & $\begin{array}{c}0.2 \\
(0.1-0.4)\end{array}$ & $\begin{array}{c}0.6 \\
(0.4-0.9)\end{array}$ \\
\hline Non-poor & $\begin{array}{c}2.5 \\
(2.2-2.9)\end{array}$ & $\begin{array}{c}0.6 \\
(0.4-0.8)\end{array}$ & $\begin{array}{c}1.2 \\
(1.0-1.5)\end{array}$ & $\begin{array}{c}0.2 \\
(0.1-0.3)\end{array}$ & $\begin{array}{c}0.4 \\
(0.3-0.6)\end{array}$ \\
\hline \multicolumn{6}{|l|}{ Education } \\
\hline Not educated & $\begin{array}{c}3.1 \\
(2.7-3.6)\end{array}$ & $\begin{array}{c}0.9 \\
(0.7-1.2)\end{array}$ & $\begin{array}{c}1.3 \\
(1.0-1.7)\end{array}$ & $\begin{array}{c}0.2 \\
(0.1-0.4)\end{array}$ & $\begin{array}{c}0.6 \\
(0.4-0.9)\end{array}$ \\
\hline Educated & $\begin{array}{c}2.1 \\
(1.8-2.5)\end{array}$ & $\begin{array}{c}0.5 \\
(0.4-0.6)\end{array}$ & $\begin{array}{c}0.9 \\
(0.7-1.1)\end{array}$ & $\begin{array}{c}0.2 \\
(0.1-0.3)\end{array}$ & $\begin{array}{c}0.4 \\
(0.3-0.6)\end{array}$ \\
\hline \multicolumn{6}{|c|}{ Type of neighborhood } \\
\hline Informal & $\begin{array}{c}2.2 \\
(1.9-2.6)\end{array}$ & $\begin{array}{c}0.7 \\
(0.5-1.0)\end{array}$ & $\begin{array}{c}0.7 \\
(0.5-0.9)\end{array}$ & $\begin{array}{c}0.2 \\
(0.1-0.3)\end{array}$ & $\begin{array}{c}0.5 \\
(0.4-0.7)\end{array}$ \\
\hline Formal & $\begin{array}{c}2.8 \\
(2.4-3.2)\end{array}$ & $\begin{array}{c}0.6 \\
(0.5-0.8)\end{array}$ & $\begin{array}{c}1.3 \\
(1.0-1.6)\end{array}$ & $\begin{array}{c}0.2 \\
(0.1-0.3)\end{array}$ & $\begin{array}{c}0.5 \\
(0.4-0.7)\end{array}$ \\
\hline \multicolumn{6}{|l|}{ Sex } \\
\hline Male & $\begin{array}{c}2.9 \\
(2.5-3.3)\end{array}$ & $\begin{array}{c}0.7 \\
(0.5-0.9)\end{array}$ & $\begin{array}{c}1.2 \\
(1.0-1.5)\end{array}$ & $\begin{array}{c}0.3 \\
(0.2-0.5)\end{array}$ & $\begin{array}{c}0.5 \\
(0.4-0.7)\end{array}$ \\
\hline Female & $\begin{array}{c}2.2 \\
(1.8-2.6)\end{array}$ & $\begin{array}{c}0.6 \\
(0.5-0.9)\end{array}$ & $\begin{array}{c}0.9 \\
(0.7-1.2)\end{array}$ & $\begin{array}{c}0.05 \\
(0.0-0.1)\end{array}$ & $\begin{array}{c}0.5 \\
(0.4-0.7)\end{array}$ \\
\hline \multicolumn{6}{|l|}{ Age group } \\
\hline $15-34$ & $\begin{array}{c}1.4 \\
(1.2-1.7)\end{array}$ & $\begin{array}{c}0.4 \\
(0.3-0.6)\end{array}$ & $\begin{array}{c}0.5 \\
(0.4-0.7)\end{array}$ & $\begin{array}{c}0.2 \\
(0.1-0.3)\end{array}$ & $\begin{array}{c}0.3 \\
(0.2-0.4)\end{array}$ \\
\hline $35-59$ & $\begin{array}{c}5.1 \\
(4.4-5.9)\end{array}$ & $\begin{array}{c}1.2 \\
(0.9-1.6)\end{array}$ & $\begin{array}{c}2.4 \\
(1.0-3.0)\end{array}$ & $\begin{array}{c}0.2 \\
(0.1-0.4)\end{array}$ & $\begin{array}{c}1.0 \\
(0.8-1.4)\end{array}$ \\
\hline Total & $\begin{array}{c}2.5 \\
(2.3-2.8)\end{array}$ & $\begin{array}{c}0.7 \\
(0.5-0.8)\end{array}$ & $\begin{array}{c}1.1 \\
(0.9-1.3)\end{array}$ & $\begin{array}{c}0.2 \\
(0.1-0.3)\end{array}$ & $\begin{array}{c}0.5 \\
(0.4-0.6)\end{array}$ \\
\hline
\end{tabular}

NB: $95 \%$ confidence interval in brackets.

Based on further analysis with control for place of birth, we observe that the all-cause mortality for migrants is higher than for non-migrant residents (Table 5). The excess mortality of migrants is explained by their greater mortality by non-communicable diseases and external causes. As expected, age is positively associated-with all-cause mortality both among migrants and city natives. Observed social inequalities in mortality for natives seem to point to the existence of an urban health penalty among the urban poor, especially from communicable diseases. Uneducated natives also experience a higher all-causes mortality rate. Natives living in informal neighborhoods have a somewhat higher mortality rate, though differences are not significant. Inequalities in mortality among migrants, however, are counterintuitive. For mortality from communicable diseases, the wealthier migrants have the same death rate as poorer migrants, educated migrants have the same mortality rate as uneducated migrants, and those who live in informal settlements have 
the same death rate as migrants in formal areas. In contrast, the mortality rate from non-communicable diseases is higher among wealthier migrants than among their poorer counterparts, and migrants living in formal neighborhoods also have a higher mortality rate compared to those in informal neighborhoods. External cause mortality does not show any significant difference, except that male migrants have a higher mortality rate for injuries compared to their female counterparts.

TABLE 5 Mortality rates by cause of death and migration status

\begin{tabular}{|c|c|c|c|c|c|c|c|c|}
\hline \multirow[b]{2}{*}{ Variables } & \multicolumn{4}{|c|}{ Non migrants } & \multicolumn{4}{|c|}{ Migrants } \\
\hline & All causes & $\begin{array}{c}\text { Communi- } \\
\text { cable } \\
\text { diseases }\end{array}$ & $\begin{array}{c}\text { Non commu- } \\
\text { nicable } \\
\text { diseases }\end{array}$ & $\begin{array}{c}\text { External } \\
\text { causes of } \\
\text { death }\end{array}$ & $\begin{array}{c}\text { All } \\
\text { causes }\end{array}$ & $\begin{array}{l}\text { Communi- } \\
\text { cable } \\
\text { diseases }\end{array}$ & $\begin{array}{c}\text { Non commu- } \\
\text { nicable } \\
\text { diseases }\end{array}$ & $\begin{array}{c}\text { External } \\
\text { causes of } \\
\text { death }\end{array}$ \\
\hline \multicolumn{9}{|l|}{ Standard of living } \\
\hline Poor & $\begin{array}{c}2.4 \\
(1.7-3.5)\end{array}$ & $\begin{array}{c}0.9 \\
(0.6-1.7)\end{array}$ & $\begin{array}{c}1.1 \\
(0.6-1.9)\end{array}$ & 0.0 & $\begin{array}{c}2.6 \\
(2.1-3.2)\end{array}$ & $\begin{array}{c}0.7 \\
(0.5-1.1)\end{array}$ & $\begin{array}{c}0.7 \\
(0.5-1.0)\end{array}$ & $\begin{array}{c}0.3 \\
(0.2-0.5)\end{array}$ \\
\hline Non-poor & $\begin{array}{c}1.4 \\
(1.0-1.9)\end{array}$ & $\begin{array}{c}0.4 \\
(0.2-0.6)\end{array}$ & $\begin{array}{c}0.6 \\
(0.4-1.0)\end{array}$ & $\begin{array}{c}0.1 \\
(0.0-0.3)\end{array}$ & $\begin{array}{c}3.1 \\
(2.6-3.6)\end{array}$ & $\begin{array}{c}0.7 \\
(0.5-1.0)\end{array}$ & $\begin{array}{c}1.5 \\
(1.2-1.9)\end{array}$ & $\begin{array}{c}0.2 \\
(0.1-0.4)\end{array}$ \\
\hline \multicolumn{9}{|c|}{ Level of Education } \\
\hline Not educated & $\begin{array}{c}2.8 \\
(1.9-4.1)\end{array}$ & $\begin{array}{c}1.0 \\
(0.5-1.9)\end{array}$ & $\begin{array}{c}1.2 \\
(0.7-2.1)\end{array}$ & 0.0 & $\begin{array}{c}3.2 \\
(2.7-3.8)\end{array}$ & $\begin{array}{c}0.9 \\
(0.6-1.2)\end{array}$ & $\begin{array}{c}1.3 \\
(1.0-1.7)\end{array}$ & $\begin{array}{c}0.2 \\
(0.1-0.4)\end{array}$ \\
\hline Educated & $\begin{array}{c}1.4 \\
(1.0-1.8)\end{array}$ & $\begin{array}{c}0.4 \\
(0.2-0.7)\end{array}$ & $\begin{array}{c}0.7 \\
(0.4-1.0)\end{array}$ & $\begin{array}{c}0.1 \\
(0.0-0.3)\end{array}$ & $\begin{array}{c}2.6 \\
(2.2-3.1)\end{array}$ & $\begin{array}{c}0.6 \\
(0.4-0.9)\end{array}$ & $\begin{array}{c}1.1 \\
(0.8-1.4)\end{array}$ & $\begin{array}{c}0.2 \\
(0.1-0.4)\end{array}$ \\
\hline \multicolumn{9}{|c|}{ Type of neighborhood } \\
\hline Informal & $\begin{array}{c}1.9 \\
(1.3-2.9)\end{array}$ & $\begin{array}{c}0.9 \\
(0.5-1.6)\end{array}$ & $\begin{array}{c}0.7 \\
(0.3-1.3)\end{array}$ & 0.0 & $\begin{array}{c}2.3 \\
(1.9-2.8)\end{array}$ & $\begin{array}{c}0.7 \\
(0.5-0.9)\end{array}$ & $\begin{array}{c}0.7 \\
(0.5-1.0)\end{array}$ & $\begin{array}{c}0.2 \\
(0.1-0.4)\end{array}$ \\
\hline Formal & $\begin{array}{c}1.6 \\
(1.2-2.2)\end{array}$ & $\begin{array}{c}0.4 \\
(0.2-0.7)\end{array}$ & $\begin{array}{c}0.8 \\
(0.6-1.2)\end{array}$ & $\begin{array}{c}0.1 \\
(0.0-0.3)\end{array}$ & $\begin{array}{c}3.5 \\
(3.0-4.1)\end{array}$ & $\begin{array}{c}0.8 \\
(0.6-1.1)\end{array}$ & $\begin{array}{c}1.7 \\
(1.3-2.1)\end{array}$ & $\begin{array}{c}0.3 \\
(0.1-0.5)\end{array}$ \\
\hline \multicolumn{9}{|l|}{ Sex } \\
\hline Male & $\begin{array}{c}1.6 \\
(1.2-2.3)\end{array}$ & $\begin{array}{c}0.4 \\
(0.2-0.8)\end{array}$ & $\begin{array}{c}0.8 \\
(0.5-1.3)\end{array}$ & $\begin{array}{c}0.05 \\
(0.0-0.3)\end{array}$ & $\begin{array}{c}3.4 \\
(2.9-4.0)\end{array}$ & $\begin{array}{c}0.8 \\
(0.6-1.1)\end{array}$ & $\begin{array}{c}1.4 \\
(1.1-1.8)\end{array}$ & $\begin{array}{c}0.4 \\
(0.3-0.7)\end{array}$ \\
\hline Female & $\begin{array}{c}1.8 \\
(1.3-2.5)\end{array}$ & $\begin{array}{c}0.7 \\
(0.4-1.2)\end{array}$ & $\begin{array}{c}0.7 \\
(0.4-1.2)\end{array}$ & $\begin{array}{c}0.05 \\
(0.0-0.3)\end{array}$ & $\begin{array}{c}2.3 \\
(1.9-2.8)\end{array}$ & $\begin{array}{c}0.6 \\
(0.4-0.9)\end{array}$ & $\begin{array}{c}1.0 \\
(0.7-1.3)\end{array}$ & $\begin{array}{c}0.05 \\
(0.0-0.2)\end{array}$ \\
\hline \multicolumn{9}{|l|}{ Age Group } \\
\hline $15-34$ & $\begin{array}{c}1.2 \\
(0.8-1.6)\end{array}$ & $\begin{array}{c}0.5 \\
(0.3-0.8)\end{array}$ & $\begin{array}{c}0.4 \\
(0.3-0.7)\end{array}$ & $\begin{array}{c}0.1 \\
(0.0-0.2)\end{array}$ & $\begin{array}{c}1.6 \\
(1.3-2.0)\end{array}$ & $\begin{array}{c}0.4 \\
(0.2-0.6)\end{array}$ & $\begin{array}{c}0.5 \\
(0.4-0.8)\end{array}$ & $\begin{array}{c}0.2 \\
(0.1-0.4)\end{array}$ \\
\hline $35-59$ & $\begin{array}{c}4.0 \\
(2.8-5.6)\end{array}$ & $\begin{array}{c}0.7 \\
(0.3-1.6)\end{array}$ & $\begin{array}{c}2.2 \\
(1.4-3.5)\end{array}$ & 0.0 & $\begin{array}{c}5.4 \\
(4.6-6.3)\end{array}$ & $\begin{array}{c}1.4 \\
(1.0-1.9)\end{array}$ & $\begin{array}{c}2.5 \\
(2.0-3.1)\end{array}$ & $\begin{array}{c}0.3 \\
(0.2-0.6)\end{array}$ \\
\hline Total & $\begin{array}{c}1.7 \\
(1.3-2.2)\end{array}$ & $\begin{array}{c}0.5 \\
(0.4-0.8)\end{array}$ & $\begin{array}{c}0.8 \\
(0.5-1.1)\end{array}$ & $\begin{array}{c}0.05 \\
(0.0-0.2)\end{array}$ & $\begin{array}{c}2.9 \\
(2.6-3.3)\end{array}$ & $\begin{array}{c}0.7 \\
(0.6-0.9)\end{array}$ & $\begin{array}{c}1.2 \\
(1.1-1.4)\end{array}$ & $\begin{array}{c}0.2 \\
(0.2-0.4)\end{array}$ \\
\hline
\end{tabular}

NB: $95 \%$ confidence interval in brackets.

\section{Multivariate results}

Table 6 and 7 present the results of the multivariate analysis. They contain hazards ratios for all-cause mortality and cause-specific mortality. They point out significant inequalities, except for mortality from exter- 
nal causes (Table 6) ${ }^{8}$ and mortality from communicable diseases among the natives (Table 7). Results show the expected higher mortality among older adults, regardless of cause of death and this holds both for migrants and natives (Tables 6 and 7). For example, all-cause mortality risk increases by $6 \%$ with each additional year of life (Table 6). This increase is estimated at about $6 \%$ among migrants and $5 \%$ for natives (Table 7). Gender is significantly related to all-cause mortality, with women experiencing lower risks (Table 6). This advantage appears to be the sum of a lower risk of dying from both non-communicable diseases and external causes, but due to small numbers, the differences are not statistically significant for individual groups of causes (Table 6). While there is no significant difference by gender for natives, migrant women enjoy a lower risk of death.

Among the three indicators of social inequality, only the type of neighborhood has a significant association with overall mortality. The paradox observed in the bivariate analysis where adults living in formal neighborhoods have a comparative mortality disadvantage is confirmed in the multivariate analysis ( $\mathrm{HR}=1.35$; Table 6$)$. This seems to be due to a higher risk of death from non-communicable causes $(\mathrm{HR}=1.72$; Table 6).

TABLE 6 Hazards ratios for all-cause mortality and mortality by cause

\begin{tabular}{|c|c|c|c|c|}
\hline Variables & All causes & $\begin{array}{c}\text { Communicable } \\
\text { diseases }\end{array}$ & $\begin{array}{c}\text { Non communicable } \\
\text { diseases }\end{array}$ & $\begin{array}{c}\text { External causes } \\
\text { of death }\end{array}$ \\
\hline \multicolumn{5}{|c|}{ Standard of living } \\
\hline Poor & 1 & 1 & 1 & 1 \\
\hline Non poor & 0.87 & 0.80 & 1.28 & 0.69 \\
\hline \multicolumn{5}{|c|}{ Level of Education } \\
\hline Not educated & 1 & 1 & 1 & 1 \\
\hline Educated & 0.92 & 0.87 & 0.89 & 0.85 \\
\hline \multicolumn{5}{|c|}{ Type of neighborhood } \\
\hline Informal & 1 & 1 & 1 & 1 \\
\hline Formal & $1.35^{* *}$ & 0.98 & $1.72 * * *$ & 1.36 \\
\hline \multicolumn{5}{|l|}{ Sex } \\
\hline Male & 1 & 1 & 1 & 1 \\
\hline Female & $0.80 * *$ & 0.97 & 0.80 & 0.16 \\
\hline Age & $1.06 * * *$ & $1.05^{* * *}$ & $1.07 * * *$ & 1.02 \\
\hline Wald statistic & $126.03 * * *$ & $44.47 * * *$ & $106.70 * * *$ & 2.00 \\
\hline
\end{tabular}

8. The absence of significant relationship is confirmed by the Wald test on the overall significance of the model. 
The multivariate analysis of mortality by migrant status shows that the previously mentioned paradox appears only among migrants (Table 7). This analysis indicates a higher risk of death for migrants living in formal settlements ( $\mathrm{HR}=1.41$; Table 6 ), especially from non-communicable diseases ( $\mathrm{HR}=1.62$ ). Wealthy migrants are also at a higher risk of dying from non-communicable diseases ( $\mathrm{HR}=1.83$ ).

Among urban natives, in contrast, the relationship with standard of living is as expected with better-off natives having lower mortality, precisely from non-communicable diseases (Table 7). The relationship also skews in the expected direction with regards to communicable diseases, showing a lower risk of death among the wealthier natives even if the difference is not very significant (Table 7). It also goes in the anticipated direction when the educated natives are compared to their uneducated counterparts, even if the difference is not statistically significant (Table 7). Urban natives who live in informal neighborhoods are not at a greater risk of death.

TABLE 7 Mortality hazards ratios controlling for migration status

\begin{tabular}{|c|c|c|c|c|c|c|}
\hline \multirow[b]{2}{*}{ Variables } & \multicolumn{3}{|c|}{ Natives } & \multicolumn{3}{|c|}{ Migrants } \\
\hline & $\begin{array}{c}\text { All } \\
\text { causes }\end{array}$ & $\begin{array}{l}\text { Communi- } \\
\text { cable diseases }\end{array}$ & $\begin{array}{l}\text { Non commu- } \\
\text { nicable di- } \\
\text { seases }\end{array}$ & All causes & $\begin{array}{l}\text { Communi- } \\
\text { cable diseases }\end{array}$ & $\begin{array}{l}\text { Non commu- } \\
\text { nicable di- } \\
\text { seases }\end{array}$ \\
\hline \multicolumn{7}{|l|}{ Standard of living } \\
\hline Poor & 1 & 1 & 1 & 1 & 1 & 1 \\
\hline Non poor & $0.53^{* * *}$ & 0.53 & $0.45^{* *}$ & 0.99 & 0.92 & $1.83^{* *}$ \\
\hline \multicolumn{7}{|c|}{ Level of Education } \\
\hline Not educated & 1 & 1 & 1 & 1 & 1 & 1 \\
\hline Educated & 0.74 & 0.63 & 0.97 & 0.98 & 0.90 & 0.88 \\
\hline \multicolumn{7}{|c|}{$\begin{array}{l}\text { Type of neighbor- } \\
\text { hood }\end{array}$} \\
\hline Informal & 1 & 1 & 1 & 1 & 1 & 1 \\
\hline Formal & 1.24 & 0.62 & 2.01 & $1.41 * *$ & 1.12 & $1.62^{* *}$ \\
\hline \multicolumn{7}{|l|}{ Sex } \\
\hline Male & 1 & 1 & 1 & 1 & 1 & 1 \\
\hline Female & 1.13 & 1.78 & 0.93 & $0.73^{* *}$ & 0.79 & 0.78 \\
\hline Age & $1.05^{* * *}$ & 1.02 & $1.07^{* * *}$ & $1.06 * * *$ & $1.06 * * *$ & $1.07^{* * *}$ \\
\hline Wald statistic & $38.48 * * *$ & 6.25 & $29.36 * * *$ & $164.51 * * *$ & $47.44 * * *$ & $103.41 * * *$ \\
\hline
\end{tabular}

NB: ${ }^{*} p<0.1 ; * *<0.05 ; * * * p<0.001$.

\section{Discussion}

Based on data for adults aged 15-49 under surveillance by the Ouagadougou HDSS, we found that wealth is apparently not associated with 
lower mortality and that adults have a higher risk of dying from noncommunicable diseases in formal than in informal settlements. While the lack of a significant relationship between wealth and mortality from communicable diseases is surprising, the lower risk of dying from noncommunicable diseases in informal neighborhoods is even less expected. The informal neighborhoods at the periphery of Ouagadougou are not marked by particularly high rates of crime or violence. Adults living in informal neighborhoods could theoretically have death rates similar to those of adults living in formal areas once education and livings standards are controlled for. Our results, however, show that adults living in formal areas face greater risk of dying prematurely compared to adults in informal areas, controlling for the other social characteristics.

These unexpected mortality differentials are noteworthy and lead to the question of whether non-poor city dwellers are more inclined to engage in the unhealthy urban life styles that lead to non-communicable diseases, and/or whether they have difficulty accessing care for these diseases. Our analysis suggests, however, that selective migration and specificities linked to the migrant status might explain these counter-intuitive results.

African cities are home to intensive migration processes, and informal settlements in particular are populated mainly by people born in rural areas (Konseiga et al., 2009). Half of Ouagadougou's rapid population growth (from 750'000 inhabitants in 1996 to 1.5 million in 2006) is due to migration, primarily from rural areas (Guengant, 2009). Migrants tend to be poorer than urban born residents, and they often live in informal parts of the city. Restricting the analysis to people born in Ouagadougou, we found that wealthy non-migrant adults are at lower risk of death, whatever the cause. As opposed to the hypothesis outlined above (which is that wealthier adults may be more prone to engage in unhealthy life-style and may not be advantaged in accessing health care for non-communicable diseases), wealthier adults born in Ouagadougou actually fare better in terms of health, both for communicable and noncommunicable diseases in the neighborhoods under study. This is consistent with the literature on the health penalty of urban poor. The results for residents born outside of the capital (people who migrated to the city at some point in their life) are strikingly different. Non-poor migrants and migrants living in formal areas have higher risks of dying prematurely from non-communicable diseases.

Selective migration and specificities related to the migration process probably explain these mortality differentials specific to migrants. Poorer migrants with non-communicable diseases may leave Ouagadougou 
to seek more affordable health care and greater social support in their places of origin (often villages), especially when they live in informal areas. This assumption goes in the same direction as the results of a study in South Africa where sick and dying migrants in cities move back to their villages (Clark et al., 2007). At the opposite, wealthy migrants and migrants living in formal areas may be more prone to host family members with a non-communicable condition, who came to live with them over long periods of time to benefit from the health services available in the city and from the support of their wealthy parent (Norman et al., 2005). Finally, the higher mortality rate from non-communicable diseases among migrants compared to natives suggests that the migration process itself may induce stress, a leading factor of hypertension (DinDzietham et al., 2004; Greiner et al., 2004).

We can only hypothesize here about the reasons for the higher mortality from non-communicable diseases by wealthier migrants and migrants living in formal areas. Further research is needed to uncover these reasons. This study has two main limitations in addition to the uncertainties related to the verbal autopsy tool. First, we are working with only three years of data with a limited number of deaths for analysis. Second, we capture migration through a rather simple measure, place of birth, which may hide more complex relationships between health and migration. More years of data will help us distinguish between different types of migrants (according to their place of birth, year at arrival in the capital, duration of stay, etc.).

\section{Conclusion}

When restricting the analysis to adults born in Ouagadougou, we found that the urban poor face an important health penalty, as expected from the literature: richer individuals have lower risks of premature death whatever the cause (communicable or non-communicable diseases). Natives living in informal areas are at relative greater risks of dying from communicable diseases. Adult migrants exhibit very different patterns of mortality, which blur the overall picture of health inequalities in the city. Wealthier adult migrants do not have a lower risk of dying before 60; rather, they are at a greater risk of non-communicable mortality. Migrants living in formal areas do not have a lower risk of dying before 60; rather, they are at a greater risk of non-communicable mortality. These particular patterns are probably due to selective migration and other specificities related to the migration process. These mortality spe- 
cificities of migrants mask the classical social gradient of adult health at the periphery of Ouagadougou. These results call for more attention to the effects introduced by migration when studying rural-urban and social differentials of health in Sub-Saharan Africa.

\section{Acknowledgements}

This work was funded by the Wellcome Trust, grant number WT081993MA. We thank Leigh Senderowicz for editing and translating this paper. A special thought to the adults we knew who died prematurely during the writing of this paper.

\section{References}

Aluson P. D. (1995), Survival Analysis Using SAS. A Pratical Guide, SAS Institute Inc., Cary, 292 p.

Azur M. J., Stuart E. A., Frankagis C., Leaf P. (2011), "Multiple Imputation by Chained Equations: What Is It and How Does It Work?», International Journal of Methods in Psychiatric Research, 20, pp. 40-49, http://dx.doi.org/10.1002/mpr.329.

BAKer J., SCHULeR N. (2004), «Analyzing Urban Poverty: A Summary of Methods and Approaches», World Bank Policy Research Working Paper, 3’399, 66 p.

BAYA B., ZIDA H., BONKoungou Z. (2009), Recensement général de la population et de l'habitation 2006 (RGPH 2006). Rapport d'analyse des données du RPGH 2006. Thème 07: La mortalité, Institut National de la Statistique et de la Démographie, Ouagadougou, $96 \mathrm{p}$.

Bocquier P., Beguy D., Zulu E., Muindi K., Konseiga K. A., Yé Y. (2011a), «Do Migrant Children Face Greater Health Hazards in Slum Settlements? Evidence from Nairobi, Kenya», Journal of Urban Health, 88, pp. 266-281, http://dx.doi.org/10.1007/ s11524-010-9497-6.

Bocquier P., Madise N. J., Zulu E. M. (2011b), «ls There an Urban Advantage in Child Survival in Sub-Saharan Africa? Evidence from 18 Countries in the 1990s», Demography, 48, pp. 531-558, http://dx.doi.org/10.1007/s13524-011-0019-2.

Clark S. J., Collinson M. A., Kahn K., Drullinger K., Tollman S. M. (2007), «Returning Home to Die: Circular Labour Migration and Mortality in South Africa», Scandinavian Journal of Public Health, 35 (Suppl. 69), pp. 35-44, http://dx.doi.org/10. 1080/14034950701355619. 
Cutler D., Deaton A., Leras-Muney A. (2006). "The Determinants of Mortality», Journal of Economic Perspectives, 20 (3), pp. 97-120, http://dx.doi.org/10.1257/jep. 20.3.97.

Dalal S., Beunza J. J., Volmink J., Adebamowo C., Bajunirwe F., NJelekela M., Mozaffarian D., fawzi W., Willett W., Adamiand H. O., Holmes M. D. (2011), «NonCommunicable Diseases in Sub-Saharan Africa: What we Know Now», International Journal of Epidemiology, 40, pp. 885-901, http://dx.doi.org/10.1093/ije/dyr050.

Din-Dzietham R., Nemhard W. N., Collins R., Davis S. K. (2004), «Perceived Stress Following Race-Based Discrimination at Work is Associated with Hypertension in African-Americans. The Metro Atlanta Heart Disease Study, 1999-2001», Social Science \& Medicine, 58, pp. 449-461, http://dx.doi.org/10.1016/S0277-9536(03) 00211-9.

Fine J. P., Gray R. J. (1999), "A Proportional Hazards Model for the Subdistribution of a Competing Risk», Journal of the American Statistical Association, 94 (446), pp. 496-509, http://dx.doi.org/10.1080/01621459.1999.10474144.

Fotso J. C. (2007), «Urban-Rural Differentials in Child Malnutrition: Trends and Socioeconomic Correlates in Sub-Saharan Africa», Health \& Place, 13 (1), pp. 205223, http://dx.doi.org/10.1016/j.healthplace.2006.01.004.

Gould W. T. (1998), "African Mortality and the New Urban Penalty», Health \& Place, 4 (2), pp. 171-181, http://dx.doi.org/10.1016/S1353-8292(98)00009-4.

Graham J. W. (2009), "Missing Data Analysis: Making It Work in the Real World», Annual Review of Psychology, 60, pp. 549-576, http://dx.doi.org/10.1146/annurev. psych.58.110405.085530.

Greiner B. A., Krause N., Ragland D., Fisher J. M. (2004), «Occupational Stressors and Hypertension: A Multi-Method Study Using Observer-Based Job Analysis and Self-Reports in Urban Transit Operators", Social Science \& Medicine, 59, pp. 1'0811 '094.

Guengant J. P. (2009), "Évolution passée et future de la ville de Ouagadougou», F. BOyer, D. Delaunay (eds), Peuplement de Ouagadougou et développement urbain, IRD, Ouagadougou, pp. 42-49.

GÜNTHER I., HARTtgen K. (2012), «Deadly Cities? Inequalities in Mortality in SubSaharan Africa», Population and Development Review, 38 (3), pp. 469-486, http:// dx.doi.org/10.1111/j.1728-4457.2012.00512.x.

James C. D., hanson K., Pake B. M. C., Balabanova D., Gwatkin D., Hopwood I., Kırunga C., Knippenberg R., Meessen B., Morris S. S., Preker A., Souteyr Y., Tibouti A., Villeneuve P., XU K. (2006), "To Retain or Remove User Fees? Reflections on the Current Debate in Low and Middle Income Countries", Applied Health Economic \& Health Policy 2006, 5 (3), pp. 137-153, http://dx.doi.org/10.2165/00148365200605030-00001.

Kenya national Bureau of Statistics (KNBS) (2010), Demographic Health Survey (DHS), 2008-2009, Results, KNBS, Nairobi, 430 p. 
Konseiga A., Zulu E., Bocquier P., Muindi K., Beguy D., Yé Y. (2009), «Assessing the Effect of Mother's Migration on Childhood Mortality in the Informal Settlement of Nairobi», M. Collinson, K. AdAZU, M. WHITE, S. FIndLEY (eds), The Dynamics of Migrations, Health and Livelihoods, ASHGATE, Farnham \& Burlington, pp. 123-138.

Koueta F., Dao L., Yé D., Koura M., Sawadogo A. (2009), «Factors Contributing to Smoking Among Students in Ouagadougou (Burkina Faso)», Revue des Maladies Respiratoires, 26 (3), pp. 291-297, http://dx.doi.org/10.1016/S0761-8425(09) 72586-0.

Kyobutungı C., Ziraba A. K., EZeh A., Ye Y. (2008), "The Burden of Disease Profiles of Residents in Nairobi Slums: Results from a Demographic Surveillance System», Population Health Metrics, (6) 1, http://dx.doi.org/10.1186/1478-7954-6-1.

LAGARDE E. (2007), "Road Traffic Injury is an Escalating Burden in Africa and Deserves Proportionate Research Efforts", PLos Medicine, 4 (6) 170, http://dx.doi.org/ 10.1371/journal.pmed.0040170.

Macia E., Duboz P., Gueye L. (2011), «Prevalence, Awareness, Treatment and Control of Hypertension Among Adults 50 Years and Older in Dakar, Senegal», Cardiovascular Journal of Africa, 23 (5), pp. 265-269, http://dx.doi.org/10.5830/CVJA2011-039.

Montgomery M. R., HeWett P. C. (2005), «Urban Poverty and Health in Developing Countries: Household and Neighborhood Effects», Demography, 42 (3), pp. 397425, http://dx.doi.org/10.1353/dem.2005.0020.

Montgomery M. R., Stren R., COHEN B., REED H. (2004), Cities Transformed: Demographic Change and Its Implications in the Developing World, Earthscan, London, $529 \mathrm{p}$.

NoRman P., Boyle P., ReEs P. (2005), «Selective Migration, Health and Deprivation: A Longitudinal Analysis», Social Science \& Medicine, 60 (12), pp. 2'755-2'771.

Ouedraogo H. Z., Fournet F., Martin-Prevel Y., Gary J., Henry M. C., Salem G. (2008), "Socio-Spatial Disparities of Obesity Among Adults in the Urban Setting of Ouagadougou, Burkina-Faso», Public Health Nutrition, 11, pp. 1'280-1'287.

Pison G., Soura A., Rossier C. (2012), Les accidents, une cause importante de morbidité et de mortalité en Afrique subsaharienne. Une étude de cas en milieu urbain défavorisé : Ouagadougou, Paper presented at the XVII International Conference of AIDELF (Association Internationale des Démographes de Langue Française), Ouagadougou, November 12-17, $20 \mathrm{p}$.

Raghunathan T. E., Lepkowski J. M., Van Hoewyk J., Solenberger P. (2001), «A Multivariate Technique for Multiply Imputing Missing Values Using a Sequence of Regression Models», Survey Methodology, 27, pp. 85-95. 
Rossier C., Soura A., Baya B., Compaore G., Dabire B., Dos Santos S., Duthé G., Gnoumou B., Kobiane J.-F., Kouanda S., LANKoAnde B., Legrand T., Mbacke C., Millogo R., Mondain N., Montgomery M., Nikiema A., Oolli I., Pison G., Randall S., SANGL G., SChOUMAKeR B., ZourkhaleinI Y. (2012), "The Ouagadougou Health and Demographic Surveillance System», International Journal of Epidemiology, 41 (3), pp. 658-666, http://dx.doi.org/10.1093/ije/dys090.

Rossier C., Soura A., Lankoande B., Millogo R. (2011), Observatoire de Population de Ouagadougou. Données du RO, R1 et R2 : Rapport descriptif, ISSP, Ouagadougou, $71 \mathrm{p}$.

TIMAeUs I. M., LUSH L. (1995), "Intra-Urban Differentials in Child Health», Health Transition Review, 5 (2), pp. 163-90.

Van BuUren S., Boshuizen H. C., KNook D. L. (1999), «Multiple Imputation of Missing Blood Pressure Covariates in Survival Analysis», Statistics in Medicine, 18, pp. 681694, http://dx.doi.org/10.1002/(SICI)1097-0258(19990330)18:6<681::AID-SIM71>3. $0 . \mathrm{CO} ; 2-\mathrm{R}$.

Who, Un-Habitat (2010), Hidden Cities, Unmasking and Overcoming Health Inequities in Urban Settings, Geneva \& Nairobi, 100 p.

Zeba A., Delisle H., Renier G., Savadogo B., Baya B. (2012), «The Double Burden of Malnutrition and Cardio-Metabolic Risk Widens the Gender and Socioeconomic Health Gap: A Study Among Adults in Burkina Faso (West Africa)", Public Health Nutrition, 15 (12), pp. 2'210-2'219. 